DOI https://doi.org/10.30525/978-9934-26-180-0-3

\title{
СПЕЦИФИКА ИСПОЛЬЗОВАНИЯ КОМПАРАТИВНЫХ КОНСТРУКЦИЙ В ПРОИЗВЕДЕНИЯХ ВИКТОРИИ ТОКАРЕВОЙ
}

\author{
Кендюшенко А. Г. \\ кандидат филологических наук, \\ дочент кафедры русского языка и литературы \\ Киевский национальный лингвистический университет \\ Тищенко И. Ю. \\ кандидат филологических наук, \\ дочент кафедры русского языка и литературы \\ Киевский наииональный лингвистический университет \\ г. Киев, Украина
}

Изучение сравнения как лингвистической категории позволяет сопоставить явления и предметы, сближающиеся между собой на основе какого-либо одного или нескольких признаков. Как отмечает Н. Д. Арутюнова, "сравнение указывает на подобие одного объекта другому, независимо от того, является оно постоянным или переходящим, действительным или кажущимся, ограниченным одним объектом или глобальным" [2, с.27]. Цель настоящего исследования заключается в выявлении и описании лексико-семантических характеристик компаративных конструкций в проекции на индивидуальное художественное мировоззрение В.Токаревой.

Среди разнообразных по форме и содержанию сравнительных конструкций в прозе Виктории Токаревой наиболее многочисленны простые сравнительные конструкции с союзом как, имеющие в качестве субъекта сравнения наименования людей. Такие сравнения фиксируют как поведенческие характеристики героев, так и особенности их внешнего вида, уподобляя людей животным, различным растениям, явлениям природы, предметам окружающего мира, другим людям. Сравнительная конструкция чаще всего состоит из трёх компонентов, для наименования которых обычно применяются ставшие традиционными термины: 1) то, что сравнивается, - субъект сравнения, 2) то, с чем сравнивается, объект сравнения, 3) признак, по которому сравнивается, - основание сравнения. Субъект и объект сравнения в компаративных конструкциях обладают набором различных сем, общие для них семы могут послужить 16 
основанием для сравнения. Чаще образ возникает в результате чувственного познания реальной действительности. Например, в предложении Олег был здоровенный, как бурый медведь, и такой же сутулый [8, с. 217] для сравниваемых предметов (Олег и медведь) общими являются признаки "крупный", "крепкий", "сильный", представленные прилагательным здоровенный (ср.: здоровый (прост.) - сильный, крепкого сложения). Второй признак (форма) представлен прилагательным сутульій.

В зависимости от ассоциаций, положенных в основу сравнений В.Токаревой, можно выделить следующие группы:1.Сравнения, основанные на визуальном восприятии: Джон Леннон поет, и Лена вдруг видит, какое красивое лицо у Александра: большие синие глаза, впалье виски, как y породистого коня [5, с. 316)]. 2. Сравнения, основанные на акустических впечатлениях: Нонна никогда не хвалила сына. Боялась сглазить. А тетя Тося звенела, как колокол, и прогудела мне всю голову [4, с. 59]. 3. Сравнения, основанные на чувственных ассоциациях, например: Она лупила нас рукой. Рука была как доска [4, с. 64].

Как показали наблюдения, в сравнительных оборотах В.Токаревой наиболее продуктивна первая группа. Сюда входят сравнения, созданные на основе - формы: Ей вдруг захотелось бросить полукитайцуа с его круглым, как тарелка, лицом [8, с. 384]; - цвета: Александр вышел к ним на лестничную площадку. Лицо бледное, как рыбье брюхо [5, с. 147]; Люля была вся розовая и поблескивающая, как леденеи [2, с 194]; - размера: Иногда туда допускают таких мордоворотов, что только диву даешься. Одна - маленькая, как крысенок. Другая - жирная, как свинья. Третья высокая, как баскетболист [3, с. 48]; - сопоставления аналогичных действий: Он еще не ходил, но уже ползал-стремительно, как таракан [5, с. 121]; Я была неповоротлива, как баржа [8, с. 327]; - внешних признаков, свойств предмета: Лоб блестел, и тугие щеки тоже блестели, как мытые яблоки [4, с. 71]; Его личо было плоское, в морщинах, как растрескавшаяся земля [8, с. 421].

В качестве объектов сравнения в компаративных конструкциях В. Токаревой выступают различные реалии. Их можно распределить по нескольким лексико-тематическим группам: 1) названия представителей различных социальных групп а) по профессии, по роду занятий: Рустам явился вовремя, как аристократ [2, с. 401]; Она видела, что они действуют, как карточные шулеры [3, с. 325]; Всю жизнь моим отцом разруливала, как регулировщик. Туда-сюда...[5, с. 172)]; б) по возрасту: Алечка, как старушка, везде сует свой нос [2, с. 378]; Композитор понимал, что она права, но хотел сочувствия и прощения, как подросток [2, с 311]; в) по гендерной принадлежности: Нуждался в ласке, как 8 
кислороде, и сам был ласковый, как девочка [2, с. 377]; Мирка была активная, как парень [6, с. 276]; г) по национальности: Верка клялась, стуча ла кулаком в грудь, как иыганка [3, с. 120]; А сама Мара - в халате c драконами, как японка [7, с. 132]. Как видим, основания сравнения формируют признаки, характеризующие как поведение героя, так и его внешний вид.

2) Названия представителей флоры и фауны: Длинненький, с крупными коленками на тонких ногах, как олененок [3 с. 243]; Девушка вся была засыпана светльми кудряшками, как тонкорунная овечка [2, с. 302]. Зооморфные образы, выбранные автором для описания персонажа, не только дают читателю представление о его внешности, но и позволяют выделять особенности поведения героев, описывать их эмоциональное состояние. Проследим функционирование перечисленных номинаций в контексте произведений: Она сказала, что я безынициативный, как баран в стаде [7, с. 99]; Она мягко, как кошка, спрыгнула с кровати, открыла окно [7, с. 77]; От него, как от бешеной собаки, распространялись волнение и беспокойство [2, с. 312]. Сравнения человека с реалиями мира флоры, как правило, фиксируют особенности внешнего вида героев: Миша - красив, как лилия, изысканный блондин [7, с. 170]; Я стою рядом с Лариской в глухом свитере, как репей рядом с хризантемой [2, с. 76].

3) Названия конкретных реалий быта. Предметные имена В. Токарева употребляет в компаративных конструкциях с эксплицитно выраженным основанием сравнения: Моя сестра Ленка - приземистая и прочная, как табуретка, в желтом сарафане с желтыми волосами [2, с. 387]. Специфика авторского представления о предмете номинации обнаруживается в особенностях употребления словесных единиц, выступающих в качестве признака (т. е. эксплицитно выраженного основания сравнения): приземистая и прочная. Такого рода сравнительные конструкции требуют для своей трактовки значительных усилий реципиента, поскольку для их адекватного понимания необходим учёт контекстных параметров: Надька светилась, как хрустальная люстра, и хохотала беспричинно [7 с. 121]; Втягивают в себя еду, как пылесосы [6, с. 312].

4) Названия явлений и объектов природы: Вера-заунывная, как ветер в трубе [5, с. 195]. Здесь преобладают компаративные конструкции, в которых субъект и объект сравнения сопоставляются по цветовому признаку, например: - У нее харизмы нет, - сказал Савраскин. - Она серая, как утренний рассвет [3, с. 331]; Нонна стояла бледная, как луна $[4$, c. 48$]$.

5) Названия продуктов питания и блюд. Сравнения человека с продуктами питания у В.Токаревой встречаются нечасто. В таких 
индивидуально-авторских сравнениях всегда присутствует элемент неожиданности: Ада не утомляла. Она была как франиузское пирожное: сладкое, но не приторное [6, с. 273]; Я была элементарна и пресна, как еврейская маца, которую хорошо есть с чем-то острым. Этим острым была для меня Мара [2, с. 326].

6) Антропонимы. Употребление прецедентных антропонимов в составе сравнительных оборотов является весьма продуктивным в прозе В. Токаревой. К прецедентным антропонимам относятся имена и фамилии известных исторических личностей, деятелей науки, искусства, культуры, употребление которых в образных сравнениях представляет собой вторичную номинацию: Леня стал народным героем, как Чапаев [2, с. 74]; Элегантный, как прини Чарльз, но плюет в землю [3, с. 67].

Компаративные конструкции занимают важнейшее место в идиолекте Виктории Токаревой, для которой сравнение является не только средством достижения выразительности, но и неотъемлемой частью ее индивидуальной стилистической системы. Наиболее многочисленными являются сравнения с человеком, в чем проявляется антропоцентризм языковой личности писательницы. свидетельствующий о важности для языковой личности всего, связанного с ней самой, ее бытием, сознанием, действиями, предпочтениями.

\section{Литература:}

1. Арутюнова Н.Д. Метафора и дискурс / Н.Д. Арутюнова // Теория метафоры. М.: Прогресс, 1990. 512 с.

2. Токарева В.С. Лавина / Токарева Виктория Самойловна. М.: АСТ, 2005. $432 \mathrm{c}$.

3. Токарева В.С. Одна из многих / Токарева Виктория Самойловна. M.: ACT, 2007. 316c.

4. Токарева В.С. Террор любовью / Токарева Виктория Самойловна. M.: ACT, 2008. 78 c.

5. Токарева В.С. Дерево на крыше / Токарева Виктория Самойловна. M.: ACT, 2011. $352 \mathrm{c}$.

6. Токарева В.С. Тихая музыка за стеной / Токарева Виктория Самойловна. М.: Астрель, 2014. 320 с.

7. Токарева В.С. Сволочей тоже жалко / Токарева Виктория Самойловна. М.: Азбука, 2014. 240 с.

8. Токарева В.С. Римские каникулы / Токарева Виктория Самойловна. М.: Азбука, 2015. 448 с. 